\title{
Pola Tatalaksana Farmakologis Hipertensi pada Pasien Rawat Inap di RS dr Soedirman Kebumen
}

\author{
The Pattern of Pharmacological Hypertension Management on Inpatient \\ at Hospital of dr Soedirman Kebumen \\ Gularso $^{1 *}$, Devita Ninda ${ }^{2 *}$, Fauziyati Ana ${ }^{3}$ \\ ${ }^{1}$ Departemen IImu Penyakit Dalam, Rumah Sakit Umum Daerah Kebumen, Fakultas Kedokteran, \\ Universitas Islam Indonesia \\ ${ }^{2}$ Fakultas Kedokteran, Universitas Islam Indonesia \\ ${ }^{3}$ Departemen IImu Penyakit Dalam, Fakultas Kedokteran, Universitas Islam Indonesia
}

DATA NASKAH:

Masuk: 21 Feb 2018

Direviu: 19 Mei 2018

Direvisi: 27 Sep 2018

Diterima: 8 Okt 2018

\section{*KORESPONDENSI:} larso_67@yahoo.com atau ninda.devita@gmail.com

DOI:

10.18196/mm.190121

\section{TIPE ARTIKEL:}

Research
Abstrak: Rumah sakit menduduki posisi penting untuk tatalaksana hipertensi. Tatalaksana hipertensi yang baik di rumah sakit menyebabkan tekanan darah terkontrol. Kenyataan tatalaksana hipertensi di rumah sakit saat ini belum maksimal. Penelitian ini bertujuan untuk mengetahui gambaran pola tatalaksana farmakologis hipertensi pasien rawat inap di RS dr Soedirman Kebumen tahun 2015. Penelitian ini bersifat non eksperimental deskriptif, menggunakan data rekam medis pasien dengan hipertensi tahun 2015. Variabel yang diobservasi meliputi jenis obat antihipertensi, jumlah obat, dosis obat dan capaian terapi. Sebanyak 95 pasien hipertensi rawat inap masuk kriteria inklusi. Pasien meninggal kurang dari 24 jam setelah rawat inap tidak diikutkan dalam penelitian. Golongan Calcium Channel Blocker merupakan obat yang paling sering digunakan secara tunggal maupun kombinasi (70,53\%.) Sebanyak 46\% diberikan kombinasi dua jenis obat. Kombinasi tersering yang digunakan adalah Angiotensin Receptor Blocker + Calcium Channel Blocker. Hanya 30,53\% pasien memenuh target tekanan darah saat pulang. Pola tatalaksana hipertensi di RS dr Soedirman Kebumen belum sesuai dengan JNC VIII yaitu pada pemilihan jenis dan jumlah obat berdasar stadium hipertensi. Tingkat keberhasilan terapi pada kelompok dengan komorbid sudah baik dibandingkan capaian WHO tetapi sebaliknya pada kelompok tanpa komorbid.

Kata kunci: Hipertensi; Tatalaksana Farmakologis; Rawat Inap

Abstract: Hospital hold an important position for the treatment of hypertension due to various clinical spectrum of patients can be found. Management of hypertension in the hospital can cause blood pressure under control after discharge from the hospital. The aim of this study is to analyze pharmacological management of hypertensive patients at dr. Sudirman Kebumen Hospital in 2015. This study is nonexperimental, descriptive, retrospective study using data from medical records from patient with hypertension in 2015. Charts were reviewed for types of antihypertensive drugs, the number of antihypertensive drugs and blood pressure control. Of 95 subjects included in this study. Exclusion criteria was death <24 hours after hospitalization. Major of patients were given Calcium Channel Blocker single or in combination (70,53\%). $46 \%$ patients were given a combination of two types of antihypertensive drugs. The most commonly used drug combination is Angiotensin Receptor Blocker + Calcium Channel Blocker. 30,53\% hypertension patient achieved blood pressure goal. Hypertension management at dr Soedirman Hospital Kebumen didn't accordance with JNC VIII. 
Keywords: Hypertension; Pharmacological Management; Hospitalization

\section{PENDAHULUAN}

Penderita hipertensi terus meningkat setiap tahunnya dari 600 juta di tahun 1980 menjadi 1 milliar pasien pada tahun 2008.,2 Hipertensi lebih banyak diderita penduduk di negara dengan pendapatan rendah sampai menengah di kawasan Afrika, Mediterania dan Asia Tenggara. ${ }^{2}$ Prevalensi hipertensi di Indonesia sebesar 26,5\%,3 namun hanya $36,8 \%$ yang terdiagnosis oleh tenaga kesehatan. 3,4

Hipertensi didefinisikan sebagai peningkatan tekanan darah sistolik sama dengan atau lebih dari $140 \mathrm{mmHg}$ dan atau diastolik sama dengan atau lebih dari $90 \mathrm{mmHg}$. Hipertensi dapat dibagi menjadi hipertensi esensial dan sekunder. Hipertensi esensial tidak berhubungan dengan penyebab lain seperti penyakit ginjal, aldoteronisme, pheokromositma, atau penyebab yang lain. Faktor risiko hipertensi terutama di Asia antara lain umur, merokok, obesitas, kurangnya akivitas fisik, dislipidemia, genetik maupun diabetes melitus (DM). ${ }^{2,5,6}$

Hipertensi dapat menimbulkan kerusakan organ tubuh seperti jantung, otak, ginjal, maupun mata. ${ }^{7}$ Terapi yang tepat dapat menurunkan mortalitas dan komplikasi hipertensi. ${ }^{2}$ Penelitian yang dilakukan Lisheng et al. (1998), ${ }^{8}$ pada populasi lansia menunjukkan terapi antihipertensi dapat menurunkan angka stroke dan gangguan kardiovaskuler. Joint National Commite (JNC) VIII mengeluarkan panduan terbaru tentang terapi hipertensi meliputi target terapi dan pilihan obat antihipertensi. ${ }^{9}$

Rumah sakit menduduki posisi penting untuk tatalaksana pasien hipertensi. Pasien rawat inap di rumah sakit memiliki berbagai spektrum klinis berupa pasien dengan hipertensi sejak sebelum masuk rumah sakit dengan komorbid lain, Tatalaksana yang tepat saat di rumah sakit oleh petugas kesehatan dapat menyebabkan tekanan darah terkontrol setelah pasien keluar dari rumah sakit. Kenyataan tatalaksana hipertensi di rumah sakit saat ini belum maksimal. ${ }^{10,11,12}$

Penelitian ini bertujuan untuk mengetahui kesesuaian pola tatalaksana farmakologis hipertensi pasien rawat inap yang didiagnosis hipertensi di RS dr Soedirman Kebumen tahun 2015 berdasar JNC VIII.

\section{BAHAN DAN CARA}

Penelitian ini merupakan penelitian non-eksperimental deskriptif. Penelitian dilakukan di RS dr Soedirman Kebumen pada bulan November 2016. Penelitian sudah mendapatkan persetujuan dari Ko- mite Etik FK UII untuk aspek etika dan telah mendapatkan ijin dari Direktur Rumah Sakit untuk mengambil data-data yang diperlukan.

Sampel penelitian ini adalah pasien rawat inap dengan diagnosis utama atau diagnosis tambahan hipertensi di RS dr Soedirman Kebumen tahun 2015 periode 1 Januari 2015 - 31 Desember 2015. Pasien dengan diagnosis hipertensi adalah pasien rawat inap yang didiagnosis dokter Rumah Sakit sebagai hipertensi baik sebagai diagnosis utama maupun diagnosis tambahan berdasarkan kriteria Joint National Commite (JNC) VIII. Pasien hipertensi yang meninggal dalam waktu kurang dari 24 jam setelah rawat inap tidak diikutkan dalam penelitian. Jumlah sampel penelitian dihitung dengan menggunakan rumus besar sampel, diperlukan sampel sejumlah 82 pasien. Teknik pengambilan sampel menggunakan simple random sampling dengan cara mengambil nomor urut pasien dengan kelipatan 5 .

Variabel-variabel yang dilihat adalah pola pemberian obat antihipertensi yang meliputi jenis obat, jumlah obat, dan luaran tekanan darah saat pasien pulang juga dianalisis. Variabel tersebut dibandingkan dengan pedoman dari JNC VIII.

Data semua variabel didapatkan dari rekam medis dan dokumen di RS dr Soedirman Kebumen. Data yang diperoleh diolah dan disajikan dalam bentuk distribusi frekuensi untuk masing-masing variabel.

\section{HASIL}

Terdapat sebanyak 123 kasus hipertensi rawat inap di RSUD dr Soedirman Kebumen pada periode Januari-Desember 2015 . Dari 123 kasus tersebut, 95 kasus memenuhi kriteria inklusi untuk menjadi subjek penelitian. Karakteristik subyek penelitian bisa dilihat pada Tabel 1.

Subjek penelitian sebanyak 95 pasien dengan sebaran 47 (49,47\%) laki-laki dan 48 (50,53\%) perempuan. Rerata usia subjek penelitian adalah 62,66 tahun (SD 13,67). Sebanyak 53 pasien $(55,79 \%)$ berusia di atas 60 tahun. Rerata tekanan darah saat masuk rumah sakit $185 \pm 26,5 / 102,7 \pm 16,03$ dengan $51,58 \%$ terdiagnosis krisis hipertensi menurut kriteria JNC VIII. Penyakit komorbid terbanyak yang diderita adalah DM tipe II (17,89\%). Proporsi jaminan kesehatan yang digunakan antara pasien umum, Badan Penyelenggara Jaminan Sosial (BPJS) kelas 1 atau 2, dan BPJS kelas 3 tidak jauh berbeda (27,37\% vs $369 \%$ vs $38,94 \%)$.

Distribusi jenis obat hipertensi pada pasien dengan hipertensi rawat inap RS dr Soedirman Kebumen dapa dilihat pada Tabel 2.

Hasil penelitian ini menunjukkan golongan Calsium Channel Blocker (CCB) merupakan obat yang 
Tabel 1. Karakteristik Subyek Penelitian

\begin{tabular}{|c|c|c|}
\hline Karakteristik & Frekuensi & Persentase \\
\hline \multicolumn{3}{|l|}{ Jenis Kelamin } \\
\hline Laki-laki & 47 & $49,47 \%$ \\
\hline Perempuan & 48 & $50,53 \%$ \\
\hline \multicolumn{3}{|l|}{ Usia $62.66 \pm 13.67$} \\
\hline$<60$ tahun & 42 & $44,21 \%$ \\
\hline$\geq 60$ tahun & 53 & $55,79 \%$ \\
\hline \multicolumn{3}{|l|}{ Jaminan Kesehatan } \\
\hline Umum & 26 & $27,37 \%$ \\
\hline BPJS kelas 1 dan 2 & 32 & $33,69 \%$ \\
\hline BPJS kelas 3 & 37 & $38,94 \%$ \\
\hline Tekanan & masuk & $(\mathrm{mmHg})$ \\
\hline \multicolumn{3}{|l|}{$185 \pm 26,5 / 102,7 \pm 16,03$} \\
\hline Hipertensi Stadium I & 12 & $12,63 \%$ \\
\hline Hipertensi Stadium II & 34 & $35,79 \%$ \\
\hline Krisis Hipertensi & 49 & $51,58 \%$ \\
\hline \multicolumn{3}{|l|}{ Penyakit Komorbid } \\
\hline DM Tipe II & 17 & $17,89 \%$ \\
\hline Gagal Ginjal Akut & 8 & $8,42 \%$ \\
\hline Gagal Ginjal Kronik & 3 & $3,16 \%$ \\
\hline Dislipidemia & 6 & $6,32 \%$ \\
\hline Stroke & 12 & $12,63 \%$ \\
\hline Gagal Jantung & 2 & $2,11 \%$ \\
\hline Tirotoksikosis & 1 & $1,05 \%$ \\
\hline $\begin{array}{l}\text { Penyakit } \\
\text { Koroner }\end{array}$ & 1 & $1,05 \%$ \\
\hline Gangguan Irama Jantung & 2 & $2,11 \%$ \\
\hline
\end{tabular}

paling sering digunakan (70,53\%), baik diberikan secara tunggal maupun kombinasi. Angiotensin Receptor Blocker (ARB) menduduki tempat kedua setelah CCB $(57,89 \%)$. Kelas obat lain yang digunakan adalah Angiotensin Converting Enzym (ACE) Inhibitor (ACEI), Alpha Agonis (AA), Beta Blocker (BB) dan Diuretik (Tabel 2).

Berdasarkan distribusi jenis obat antihipertensi berdasar penyakit komorbid pada Tabel 3. ditemukan beberapa penyakit komorbid yang menyertai hipertensi. Angiotensin Receptor Blocker adalah obat yang paling banyak diberikan pada pasien hipertensi dengan penyakit komorbid kecuali dengan tirotoksikosis baik diberikan secara tunggal ataupunkombi-

Tabel 2. Distribusi Jenis Obat Hipertensi pada Pasien dengan Hipertensi Rawat Inap RS dr Soedirman Kebumen

\begin{tabular}{lc}
\hline Kelas Obat & Persentase* $^{*}$ \\
\hline ACE Inhibitor & 10,51 \\
Angiotensin Receptor Blocker (ARB) & 57,89 \\
Calcium Channel Blocker (CCB) & 70,53 \\
Alpha Agonis (AA) & 1,05 \\
Beta Blocker (BB) & 4,2 \\
Diuretik & 7,27
\end{tabular}

*jumlah dibagi dengan total subjek penelitian
Tabel 3. Distribusi Jenis Obat Antihipertensi Berdasar Penyakit Komorbid

\begin{tabular}{|c|c|}
\hline Komorbid & Persentase $^{*}$ \\
\hline \multicolumn{2}{|l|}{ Diabetes Melitus $(n=17)$} \\
\hline ARB & 35,29 \\
\hline $\mathrm{CCB}$ & 35,29 \\
\hline $\mathrm{ARB}+\mathrm{CCB}$ & 17,65 \\
\hline $\mathrm{ACEI}+\mathrm{CCB}$ & 5,88 \\
\hline $\mathrm{ARB}+\mathrm{CCB}+\mathrm{AA}$ & 5,88 \\
\hline \multicolumn{2}{|l|}{ Gagal Ginjal Akut $(n=8)$} \\
\hline ARB & 25 \\
\hline ACEI & 12,5 \\
\hline $\mathrm{ARB}+\mathrm{CCB}$ & 62,5 \\
\hline \multicolumn{2}{|c|}{ Gagal Ginjal Kronik (n=3) } \\
\hline ARB & 33,33 \\
\hline $\mathrm{ARB}+\mathrm{CCB}$ & 66,67 \\
\hline \multicolumn{2}{|l|}{ Dislipidemia $(n=6)$} \\
\hline ARB & 16,67 \\
\hline $\mathrm{CCB}$ & 16,67 \\
\hline $\mathrm{ARB}+\mathrm{CCB}$ & 50 \\
\hline $\mathrm{ARB}+\mathrm{CCB}+\mathrm{ACEI}$ & 16,67 \\
\hline \multicolumn{2}{|l|}{ Stroke $(n=12)$} \\
\hline ARB & 8,33 \\
\hline $\mathrm{CCB}$ & 33,33 \\
\hline $\mathrm{ARB}+\mathrm{CCB}$ & 41,67 \\
\hline ARB+Diuretik & 8,33 \\
\hline $\mathrm{ARB}+\mathrm{CCB}+$ Diurerik & 8,33 \\
\hline \multicolumn{2}{|l|}{ Tirotoksikosis $(n=1)$} \\
\hline $\mathrm{BB}$ & 100 \\
\hline \multicolumn{2}{|l|}{ Gagal Jantung $(n=2)$} \\
\hline $\mathrm{ARB}+\mathrm{BB}+$ Diuretik & 50 \\
\hline $\mathrm{ARB}+\mathrm{CCB}+\mathrm{ACEI}$ & 50 \\
\hline \multicolumn{2}{|c|}{ Penyakit Jantung Koroner $(n=1)$} \\
\hline $\mathrm{ARB}$ & 100 \\
\hline \multicolumn{2}{|c|}{ Gangguan Irama Jantung $(n=2)$} \\
\hline $\mathrm{ARB}$ & 50 \\
\hline $\mathrm{ARB}+\mathrm{CCB}$ & 50 \\
\hline
\end{tabular}

*jumlah dibagi total sampel yang memiliki penyakit komorbid tertentu

nasi dengan antihipertensi lain. Penelitian ini menunjukkan pasien dengan komorbid DM terbanyak diterapi dengan ARB atau CCB (keduanya memiliki frekuensi 35,29\%), sedangkan pada pasien gagal ginjal kronik diterapi dengan kombinasi $A R B+C C B$ $(66,67 \%)$.

Berdasarkan distribusi jenis obat antihipertensi berdasar derajat hipertensi menunjukkan bahwa pasien dengan hipertensi stadium I, terapi farmakologis didominasi ARB dan CCB yang diberikan sebagai terapi tunggal (masing-masing sebesar 41,67\%). Hipertensi stadium II sebagian besar diberikan CCB sebagai obat tunggal $(44,12 \%)$, sedangkan pada krisis hipertensi sebanyak 48,98\% diterapi dengan kombinasi $\mathrm{ARB}+\mathrm{CCB}$.

Rerata lama rawat inap pada pasien hipertensi 
Tabel 4. Distribusi Jenis Obat Antihipertensi Berdasarkan Derajat Hipertensi

\begin{tabular}{lc}
\hline \multicolumn{1}{c}{ Derajat Hipertensi } & Persentase $^{*}$ \\
\hline Hipertensi Stadium I $(\mathbf{n}=\mathbf{1 2})$ & \\
ARB & 41,67 \\
CCB & 41,67 \\
ACEI & 8,33 \\
ARB+CCB & 16,67 \\
Hipertensi Stadium II (n=34) & \\
ARB & 5,88 \\
ACEI & 2,94 \\
CCB & 44,12 \\
BB & 5,88 \\
ARB+CCB & 29,41 \\
ARB+Diuretik & 2,94 \\
Krisis Hipertensi $(\mathbf{n}=49)$ & \\
ARB & 6,12 \\
CCB & 14,28 \\
ACEI & 6,12 \\
ARB+CCB & 48,98 \\
ARB+Diuretik & 2,04 \\
ACEI+Diuretik & 2,04 \\
ACEI+CCB & 6,12 \\
ARB+CCB+Diuretik & 2,04 \\
ARB+CCB+BB & 2,04 \\
ARB+CCB+AA & 2,04 \\
ARB+ 2 Diuretik & 2,04 \\
ACEI+CCB+BB & 2,04 \\
\hline
\end{tabular}

*jumlah dibagi total sampel pada stadium hipertensi tertentu

di RS dr Soedirman Kebumen adalah 3,5 $\pm 1,7$ hari. Rerata tekanan darah saat pulang dari rumah sakit 150,06 $\pm 23,73 / 86,03 \pm 14,22$ (Tabel 5.). Menurut rekomendasi dari JNC VIII (2014), ${ }^{13}$ target pencapaian terapi hipertensi pada populasi umum adalah $<140 / 90 \mathrm{mmHg}$. Pada penelitian ini idapatkan 30,53\% pasien memenuhi target tekanan darah saat pulang.

Beberapa kelompok khusus yang menjadi perhatian khusus sesuai rekomendasi dari JNC VIII adalah pasien hipertensi berumur $\geq 60$ tahun, pasien hipertensi dengan komorbid DM dan gagal ginjal kronik (GGK). Rumah Sakit dr Soedirman Kebumen terdapat sebanyak $43,40 \%$ pasien berusia $\geq 60$ tahun dapat memenuhi target tekanan darah saat pulang, sedangkan pasien dengan komorbid DM dan gagal ginjal kronik yang dapat memenuhi kriteria tekanan darah saat pulang lebih kecil yaitu hanya $25,53 \%$ dan $33,33 \%$ berturut-turut untuk pasien dengan komorbid DM dan GGK.

\section{DISKUSI}

Karakteristik sosiodemografi pada penelitian ini didapatkan tidak jauh berbeda antara beberapa kelompok. Pada penelitian ini didapatkan penderita hipertensi lebih banyak pada perempuan dibandingkan laki-laki $(50,53 \%)$. Rerata usia subjek penelitian adalah 62.66 tahun (SD 13,67). Hasil ini tidak jauh berbeda dengan penelitian yang dilakukan Sedayu (2015), ${ }^{14}$ di Padang Panjang, Sumatera Barat. Rata-rata umur penderita hipertensi adalah 62.06 tahun, jenis kelamin perempuan $61,2 \% .{ }^{14}$ Penyakit komorbid tersering pada penelitian ini adalah DM tipe II sebanyak $17,89 \%$. Penelitian lain yang dilakukan oleh Banegas et al. (2004), ${ }^{12}$ juga menunjukkan jumlah pasien hipertensi rawat inap dengan DM sejumlah $20,6 \%$.

Hasil penelitian ini menunjukkan golongan $C C B$ merupakan obat yang paling sering digunakan, baik diberikan secara tunggal maupun kombinasi $(70,53 \%)$. ARB menduduki tempat kedua setelah CCB dengan $57,89 \%$. Hal ini sesuai dengan panduan tatalaksana hipertensi dari JNC VIII, pilihan antihipertensi pada pasien non kulit hitam baik dengan DM atau tidak meliputi diuretik thiazid, CCB, ACEI, atau ARB. ${ }^{9}$ Penelitian lain yang dilakukan oleh Yen et al. (2012), ${ }^{15}$ memperlihatkan bahwa CCB adalah obat yang paling banyak digunakan pada

Tabel 5. Luaran Tekanan Darah pada Beberapa Kelompok

\begin{tabular}{lcccc}
\hline \multicolumn{1}{c}{ Kelompok } & $\mathbf{N}$ & $\begin{array}{c}\text { Pencapaian Target } \\
\text { Sistole dan Diastole } \\
(\%)\end{array}$ & $\begin{array}{c}\text { Pencapaian Target } \\
\text { Sistole } \\
(\%)\end{array}$ & $\begin{array}{c}\text { Pencapaian Target } \\
\text { Diastole } \\
(\%)\end{array}$ \\
\hline $\begin{array}{c}\text { Total populasi } \\
<140 / 90 \mathrm{mmHg}\end{array}$ & 95 & $\begin{array}{c}(\text { rerata } 150,06 \pm 23,73 / 86,03 \pm 14,22) \\
30,53\end{array}$ & 32,63 & 60 \\
$\begin{array}{l}\text { Umur } \\
\quad<60 \text { tahun }\end{array}$ & 42 & 26,92 & 38,09 & 53,66 \\
$\quad<140 / 90 \mathrm{mmHg}$ & & 43,40 & 45,28 & 81,39 \\
$\quad \geq 60$ tahun & & & \\
$\quad<150 / 90 \mathrm{mmHg}$ & 53 & 25,53 & 25,53 & 70,59 \\
$\begin{array}{c}\text { Diabetes Melitus } \\
<140 / 90 \mathrm{mmHg}\end{array}$ & 17 & & 33,33 & 66,67 \\
$\begin{array}{c}\text { Gagal Ginjal Kronik } \\
<140 / 90 \mathrm{mmHg}\end{array}$ & 3 & 33,33 & & \\
\hline
\end{tabular}


pasien hipertensi rawat inap tanpa komplikasi$57,41 \%$. Penelitian yang dilakukan Jainaf Nachina et al. (2015), ${ }^{16}$ di India menunjukkan ACE Inhibitor adalah obat tersering yang diresepkan $(45,21 \%)$.

Panduan terapi hipertensi dari JNC VIII memfokuskan pada dua penyakit komorbid yaitu DM dan gagal ginjal kronik. ${ }^{9}$ Menurut panduan dari JNC VIII, pasien DM dianjurkan menggunakan diuretik tipe thiazid atau $C C B,{ }^{9}$ sedangkan pasien gagal ginjal kronik dianjurkan dengan ACEI atau ARB. ${ }^{9}$ Sejalan dengan penelitian ini menunjukkan bahwa pasien dengan komorbid DM terbanyak diterapi dengan ARB atau CCB (keduanya memiliki frekuensi (35,29\%). Pada pasien gagal ginjal kronik diterapi dengan kombinasi ARB+CCB $(66,67 \%)$.

Panduan JNC VIII memberikan rekomendasi bahwa pada populasi umum dengan umur sama dengan atau lebih dari 60 tahun, terapi antihipertensi diberikan saat tekanan darah $\geq 150 / 90 \mathrm{mmHg}$, sedangkan pada pasien dengan umur kurang dari 60 tahun, terapi farmakologi dimulai saat tekanan darah $\geq 140 / 90 \mathrm{mmHg}$. Panduan sebelumnya dari JNC VIII membagi hipertensi menjadi prehipertensi, hipertensi stadium I, hipertensi stadium II dan krisis hipertensi..,9

Hipertensi stadium I diterapi dengan satu jenis obat.7 Thiazid sebagai pilihan pertama namun dapat dipertimbangkan ACEI, ARB, BB, atau CCB.7 Pada penelitian ini, Thiazid jarang diberikan, pasien dengan hipertensi stadium I didominasi ARB dan CCB yang diberikan sebagai terapi tunggal (keduanya sebesar 41,67\%). Hipertensi stadium II disaranan kombinasi dua obat berupa thiazid dengan ACEI atau ARB atau BB atau CCB,7 sedangkan hasil penelitian menunjukkan ketidaksesuaian karena hipertensi stadium II sebagian besar diberikan CCB sebagai obat tunggal (44,12\%).

Pada krisis hipertensi di RSUD dr Soedirman sebanyak 48,98\% diterapi dengan kombinasi ARB + CCB. Padahal krisis hipertensi memerlukan penanganan yang cepat. 7 Obatan parenteral lebih dianjurkan. ${ }^{11}$ Hidralazin dan Labetolol adalah obat-obatan parenteral yang sering digunakan untuk penanganan krisis hipertensi. ${ }^{11}$ Ketidaksesuaian ini mungkin dikarenakan ketersediaan obat tersebut terbatas.

Menurut rekomendasi dari JNC VIII (2014), ${ }^{13}$ target pencapaian terapi hipertensi pada populasi umum adalah $<140 / 90 \mathrm{mmHg}$. Pada penelitian ini didapatkan 30,53\% pasien sudah memenuhi target tekanan darah saat pulang. Kelompok khusus yang menjadi perhatian dari JNC VIII adalah pasien berumur $\geq 60$ tahun, komorbid DM dan gagal ginjal kronik. Sebanyak 43,40\% pasien dengan usia $\geq 60$ tahun dapat memenuhi target tekanan darah saat pulang. Hasil yang lebih rendah pada pasien dengan komorbid DM dan gagal ginjal kronik (25,53\% dan $33,33 \%)$.

Hasil peneltian ini tampak lebih baik untuk pasien dengan komorbid (17,4\% vs 25,3 dan $33,33 \%$ ) tetapi kurang baik pada pasien tanpa komorbid (43,3\% vs 46,4\%) jika dibandingkan dengan WHO. ${ }^{12}$ Hal ini mungkin dipengaruhi oleh umur, jenis kelamin, ras, jaminan kesehatan, pemberi pelayanan kesehatan dan penyakit komorbid. ${ }^{17}$ Kondisi sosiodemografi dan pemberi pelayanan kesehatan adalah faktor yang paling mempengaruhi, ${ }^{17}$

Keterbatasan penelitian ini adalah jenis data yang dipakai menggunakan data sekunder rekam medis. Data dari rekam medis terkadang tidak lengkap. Masalah ini menyebabkan data yang diambil kurang akurat.

\section{SIMPULAN}

Pola tatalaksana hipertensi di RS dr Soedirman Kebumen belum sesuai dengan JNC VIII yaitu pada pemilihan jenis dan jumlah obat berdasar stadium hipertensi. Tingkat keberhasilan terapi pada kelompok dengan komorbid sudah baik dibandingkan capaian WHO tetapi sebaliknya pada kelompok tanpa komorbid.

Diperlukan penelitian lebih lanjut tentang faktor-faktor yang mempengaruhi efektivitas obat antihipertensi pada pasien rawat inap.

\section{DAFTAR PUSTAKA}

1. WHO. Global Status Report on Noncommunicable Diseases 2010. Geneva: WHO. 2011.

2. WHO. A Global Brief on Hypertension: Silent Killer, Global Public Health Crisis. Geneva: WHO. 2013.

3. Riskesdas. Riset Kesehatan Dasar 2013. Jakarta: Kementrian Kesehatan RI. 2013.

4. Setiawan Z. Prevalensi dan Determinan Hipertensi di Pulau Jawa Tahun 2004. Jurnal Kesehatan Masyarakat Nasional, 2006; 1 (2): 57-62.

5. Carretero OA, Oparil S. Essential Hypertension. Circulation, 2000; 101 (3): 329-335.

6. Cheung BMY, Cheung TT. Challenges in the Management of Hypertension in Asia. Eur Heart J Suppl, 2012; 14 (Supplement A): A37-A38.

7. Yogiantoro M. Hipertensi Esensial, dalam Buku Ajar Ilmu Penyakit Dalam. Jakarta: Pusat Penerbitan Departemen Ilmu Penyakit Dalam FK UI. 2006.

8. Lisheng L, Ji Guang W, Lansheng G, Guozhang L, Jan AS. Comparison of Active Treatment and Placebo in Older Chinese Patients with Isolated Systolic Hypertension. J Hypertens, 1998; 16 (12): 1823-1829. 
9. James PA, Oparil S, Carter BL, Cushman WC, Dennison-Himmelfarb D, Handler J, et al. 2014 Evidence-Based Guideline for the Management of High Blood Pressure in Adults Report From the Panel Members Appointed to the Eighth Joint National Committee (JNC 8). JAMA, 2014; 311 (5): 507-520.

10. Murinson M, Roth B, Grosman E, Dicker D, Elis A. Blood Pressure Control during Hospitalization at the Department of Medicine. Arch Clin Hypertens, 2015; 1 (1): 001-004.

11. Ervin SE. Hospital Management of Hypertension: Essential and Secondary Hypertension. Hospital Medical Practice. 2014; 2 (12): 1-14.

12. Banegas JR, Segura J, Ruilope LM, Luque M, García-Robles R, Campo C, et al. Blood Pressure Control and Physician Management of Hypertension in Hospital Hypertension Units in Spain. Hypertension, 2004; 43 (6): 1338-1344.

13. JNC -8. The Eight Report of the Joint National Committee. Hypertension Guidelines: An InDepth Guide. Am J Manag Care, 2014; 20 (1 Spec No.): E8.
14. Sedayu B, Azmi S, Rahmatini. Karakteristik Pasien Hipertensi di Bangsal Rawat Inap SMF Penyakit Dalam RSUP DR. M. Djamil Padang Tahun 2013. Jurnal Kesehatan Andalas, 2015; 4 (1): 65-69.

15. Chen Y, Hu S, Shen G, Wu L, Xu W, Wang L, et al. Antihypertensive Treatment among Inpatients with Hypertension at Anhui Provincial Hospital in China: a Cross-Sectional Study. Lat Am J Pharm, 2012; 31 (2): 298-304.

16. Nachiya RAM, Parimkrisnan S, Ramakrishna Rao M. Study of Drug Utilization Pattern of Antihypertensive Medications on Out-patients and Inpatiens in a Tertiary Care Teaching Hospital: A Cross Sectional Study. African J Pharm Pharmacol, 2015; 9 (11): 383-396.

17. Potchoo Y, Goe-Akue E, Damorou F, Massoka B, Redah D, Guissou IP. Effect of Antihypertensive Drug Therapy on the Blood Pressure Control among Hypertensive Patients Attending Campus' Teaching Hospital of Lome, Togo, West Africa. Pharmacology E⿱ Pharmacy, 2012; 3 (1): 214-223. 